\title{
The Adaptation Path of Political Mobilization of the Communist Party of China under the "Strong State and Strong Society"
}

\section{Lijuan Zhang}

Sichuan Agricultural University, Ya'an City, Sichuan Province, 625014

Keywords: nation, society, political party, political mobilization, governance

\begin{abstract}
A benign and interactive relationship between the state and the society should be established to form a relationship model between strong state and strong society. In order to achieve a strong state and a strong society model, the Communist Party of China should consciously shrink the boundaries of political mobilization, regulate political mobilization, and release sufficient space for the enhancement of social power, so that political mobilization can be used as a transitional system to replace its effectiveness. In the end, the party mobilizes the society to participate in political life and turns into the conscious participation of the society.
\end{abstract}

\section{The Goal of Reshaping the Relationship between the State and Society: Strong State and Strong Society}

At present, China's state and social relations are in a state of "strong state and weak society." Under this relationship model, there are some shortcomings in the operation of China's political system and mechanism, which is not conducive to the construction of democratic politics. In the strong country-strong society model, the state and society are not a hard-hitting billiards model, but a mutually beneficial cooperation situation. The state and society each play their own functions, and the social integration of individual appeals is fed back to the state, and the state responds effectively to social needs. This can not only promote the political democratization of our country, but also maintain the country's powerful ability to govern the country and enhance the scientific nature of state decision-making.

The reconstruction of the relationship between the state and the society is the initiative of the Chinese ruling party and the government to adapt to the laws of social development. The state and society are highly integrated to the limited separation of the state and society, until the benign interaction between the two is the relationship between China and society.

\section{The Relationship between the State and Society is the Social Basis of the Political Mobilization of the Communist Party of China}

The adjustment of the relationship between the state and the society has had an important impact on the changes in the objectives, means, and contents of the political mobilization of the Communist Party of China during various periods. Since the reform and opening up, the relationship between China's state and society has been highly integrated before the reform and opening up to the limited separation of the state and society. This has had a major impact on the political mobilization of the Communist Party of China, which has changed the elements of the CCP's political mobilization, such as the subject and object, and influenced the choice of mobilization methods.

Under the highly integrated state-society relationship, the CCP's political mobilization has shown a highly centralized organizational system within the mobilization entity, that is, within the Chinese Communist Party; in the mobilization of the object, that is, social members and social organizations, the weakening of the social organization and the passive individual Participation; and the mobilization mode shows a single character, mainly based on large-scale mass movements as the main carrier.

After the reform and opening up, the state and society gradually separated, and the relationship 
between the two became increasingly rationalized. In view of the changes in the mobilization of the social foundation and the transformation of the mobilization of the main concept, the Communist Party of China has adjusted the political mobilization in a timely manner, and the political mobilization has changed in mobilizing the subject, object and mobilization. The organizational system of the mobilization subject has been weakened, and the initiative of the individuals and social organizations that mobilize the object has been brought into play, which in turn has made the mobilization mode more diversified.

\section{The Adjustment Path of the Political Mobilization of the Communist Party of China under the "Strong State and Strong Society"}

The relationship between the state and society from the high integration before the reform and opening up to the limited separation after the reform and opening up, although a great change, is still a strong national weak society relationship model. In this model, the state and society are in an unbalanced state. This unbalanced state leads to excessive emphasis on the political power of mobilizing the subject in political mobilization, while ignoring the civil rights of mobilizing the object. This kind of political mobilization is not conducive to the realization of the benign relationship between the state and society. The construction of the goal of a strong country and a strong society prompted the Chinese Communist Party to adjust its political mobilization behavior, change the political mobilization of the past administrative order, and pay attention to the function of mobilizing the object.

\subsection{Further standardizing the CCP's political mobilization.}

Political mobilization is a top-down political act that mobilizes the difference in the power and status of the subject and object, so that the political party may use the power of control in the political mobilization activities to infringe on the interests of the mobilized object, resulting in the disorder of mobilization, Extreme. To this end, it is necessary to strengthen the regulation of the political mobilization behavior of the Communist Party of China, and distinguish which areas require the Chinese Communist Party to mobilize, and which areas should be returned to the society for independent resolution. On the basis of defining the CCP's political mobilization boundary, it is necessary to strengthen the rule of law for political mobilization in the field that should be played by the CCP's political mobilization, to prevent it from breaking through the boundaries of the legal system and affecting the rule of law in China.

First, clarify the boundaries of political mobilization.

In order to enhance their ability to govern while not infringing on the interests of society, the Communist Party of China should put political mobilization in the party's self-mobilization and public crisis mobilization, and the things within the administrative system and within the scope of social autonomy should be returned to them.

First of all, the construction of the ruling party requires the Communist Party of China to play the role of political mobilization. The problems encountered in the development of the ruling party are largely caused by the unfavorable factors within the party. This requires the Chinese Communist Party to guide the behavior of party members by relying on political mobilization within the party, and strengthen it through party propaganda and education and practical learning. Party members' advanced nature education will improve the quality of party members.

Second, the resolution of public crisis events also requires the CCP to play the role of political mobilization. The outbreak of public crisis events is characterized by suddenness and publicity. It needs to be quickly reflected and acted upon, and it also needs to mobilize large-scale social resources. The political mobilization of the ruling party has such an advantage. With the top-down organizational system and the political power in its hands, the CCP can quickly integrate social resources and call for social input into crisis resolution.

In addition, for the government and society to solve things themselves, the political mobilization of the CCP should give up space and not freely intervene. On the one hand, the management of daily public affairs should be incorporated into the government's conventional bureaucracy, 
respecting part of the work within the administrative system, and rationalizing the relationship between the ruling party and the state agency. On the other hand, things within the scope of social autonomy should be returned to the society and the relationship between the ruling party and society should be straightened out.

Second, strengthen the rule of law in political mobilization.

After clarifying the boundaries of the political mobilization of the Communist Party of China, what we need to think about is how to regulate its mobilization behavior in the field that the Communist Party of China can mobilize, specifically to strengthen the rule of law in political mobilization.

First of all, to ensure the legalization of the CCP's political mobilization, it is necessary to strengthen the legislation on political mobilization, to make the mobilization behavior legal, and to improve the party's power supervision and other related supporting laws. The laws that the state has formulated related to mobilization actions are the "National Defense Mobilization Law of the People's Republic of China" officially implemented in 2010. The law of the Ministry mainly focuses on the mobilization of defense materials and military personnel by political parties and countries during the war phase. The special laws for political mobilization are basically not formulated, and mobilization cannot be relied upon. To this end, special political mobilization laws and regulations should be formulated to divide political mobilization into different levels according to their importance, to clarify the mobilization subjects of different levels of political mobilization, and the scope of powers and responsibilities, and to formulate a negative list of political mobilization. In addition to the formulation of special laws for political mobilization, other supporting laws must be improved. In our country, the phenomenon of non-standardization and disorder in the process of political mobilization is mainly because the power to mobilize the subject is not subject to limited restraint and supervision. To this end, while formulating the special law of political mobilization, we must improve laws and regulations on party power operation and social supervision.

In addition, we must ensure the institutionalization of the CCP's political mobilization. In the case of formulating laws related to political mobilization, it is necessary to ensure the implementation of laws and regulations through system construction and regulate the political mobilization behavior of party committees and governments at all levels. Political mobilization is mainly divided into emergency mobilization and peacetime mobilization according to the degree of urgency. The CCP should establish corresponding processing mechanisms for different types of mobilization, formulate different mobilization procedures, and realize the institutionalization and legalization of mobilization behavior.

\subsection{Further cultivating the ability of the society to take the initiative.}

The CCP's political mobilization has strengthened the country's strength through a top-down organizational system, but it may cause social autonomy to be ignored. To this end, in the process of political mobilization of the Communist Party of China, we should pay attention to the interests of members of society and social organizations, while attaching importance to the enhancement of social self-mobilization.

First, pay attention to the interests of members of society and strengthen the pertinence of mobilization.

After the reform and opening up, the state and society gradually became "individualized," but this degree of division was relatively limited. Since the social forces have not yet fully played their role, the top-down command-based mobilization method is more common in the process of CCP political mobilization. This is not conducive to the CCP's political mobilization ability, and it is also not conducive to the improvement of social autonomy. To this end, in the process of implementing political mobilization, the Communist Party of China should pay attention to the satisfaction of the interests of the object, and then adopt different mobilization methods for different objects, mobilize in a targeted manner, and enhance the sensitivity of the mobilization object to the political mobilization of the CCP. 
Political mobilization is often directed at a group, which is composed of many individuals, and the individual differences lead to heterogeneity and diversification of the group. Differentiating the audience and mobilizing in a targeted manner can greatly improve the mobilization effect and save the mobilization cost. "Contemporary China, the social group is increasing, and various new social classes are constantly appearing along with the development of the economy. This requires that the characteristics of each social class should be carefully studied when doing political mobilization, and different characteristics should be proposed for different classes. The mobilization method creates different mobilization content so that the integration of power can be achieved within the maximum scope [1]". For example, for the rich people with superior material conditions, such as entrepreneurs and private entrepreneurs, after the material wealth is satisfied, To seek political power and status, the CCP should satisfy its legitimate demands for political participation. In addition, the rich people should also pay attention to cultivating their sense of social responsibility, attach importance to the cultivation of the public spirit, enhance the sense of responsibility of the first rich spur the later rich, understand the essence of fairness and justice, and rationally treat the policies of the party and the state. For disadvantaged groups with low income and low social status, they hope to improve their living conditions and obtain social dignity. Therefore, measures such as social security, employment and household registration system reform should improve their living standards, improve their social status, and expand the identification of vulnerable groups to the political mobilization of the Chinese Communist Party. The selection of mobilization objects and the mobilization goal should be combined to carry out targeted mobilization activities. This can reduce the cost of mobilization and improve the mobilization effect, and at the same time not involve the whole society in political mobilization activities, so that political mobilization and state construction work together.

Second, attach importance to social mobilization and enhance social autonomy.

With the limited separation of China's state and society, social forces have gradually increased, social mobilization models have arisen, and social forces, especially social organizations, have gradually become the subject of social mobilization from the object of political mobilization. Although the social mobilization is in full swing, due to the immature development of social forces and the imperfect social organization, social mobilization cannot fully exert its good effects. To this end, we must combine political mobilization with social mobilization, overcome the deficiencies of political mobilization, and play the role of social mobilization.

Promoting the cooperation between political mobilization and social mobilization is essentially to strengthen the interaction and cooperation between the state and society, so that the Communist Party of China and the members of the society, the organization of the society, become the main body of social governance and participate in public affairs and social management activities. . This requires the party and the government to realize the sharing of resources with the society, establish an information linkage mechanism, social organizations and communities to timely feedback the interests of members of society, and establish a communication mechanism between the party and the government and society.

While promoting the complementarity of political mobilization and social mobilization, we must also pay attention to regulating social mobilization. After the reform and opening up, the state has consciously relaxed its control over society. "A society that has been driven by the power of breaking the market, once it awakens, it will attempt to show itself that it is completely different from the logic of state power and self-defense[2]." Social forces suddenly emerged from the long-term suppression before the reform and opening up, and activism has increased. Due to the differences in the subjective consciousness and cultural quality of members of society, some members evade self-government and are still attached to the state's administrative orders. Other members have a strong sense of interest, and there is a positive conflict with the state in the process of rights protection. The state and society have not produced a benign interaction. . To regulate social mobilization behavior, we must first cultivate the rational participation consciousness of members of society and avoid excessive emotional social mobilization. In addition, the state should pay attention to the interests of the people, protect the legitimate rights and interests of citizens, 
regulate the social mobilization behavior of citizens and social organizations through various laws and systems, prevent social mobilization from becoming a social incitement, and make social mobilization not deviate from the national modernization drive. .

China's national construction and social growth are advancing toward the goal of strengthening the country and strengthening society. At present, the lack of social power and the lack of social autonomy are major obstacles to balancing the relationship between the state and society. As a bridge between the state and society, political parties should standardize and adapt their political behaviors, "going out of the country" and "sneaking into" the society and avoiding "party cartelization [3]". The Communist Party of China should face up to the two sides of political mobilization. With the increasing social autonomy, it should timely retreat the tentacles of political mobilization, clarify the boundaries of political mobilization, and leave room for the exertion of social forces.

\section{References}

[1] Yang Yuguang. Historical Investigation and Contemporary Value of Red Slogans in Central Soviet Area [D]. Nanchang: Nanchang University, 2010.112

[2] Ren Jiantao. The rise of society_ - the core issue of social management innovation [M]. Beijing: Xinhua Press, 2013: 3.28

[3] Sun Peijun. Research on the Party and Social Resistance Governance in the Change of Power Structure [J]. China Social Public Security Research Report (3rd Series), 2013(2): 203-221. 